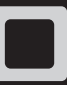

Alma

Hija de la Violencla

CINE

TÍTULO ORIGINAL: "AIma, hija de la violencia";

AÑO: 2013; DURACIÓN: 54:08 minutos;

PAÍS: Francia;

DIRECTORES: Miquel Dewever Plana -

IsabelleFougère;

PRODUCTORA: Upian / Arte / Vu Agency;

GÉNERO: Documental.

\title{
Alma, hija de la violencia
}

Documental basado en el testimonio de Alma, una joven que con mucho sentimiento, "desde el corazón" como ella dice, comparte su experiencia de lo que implica ser parte de una de las principales pandillas en Guatemala. A lo largo de su testimonio, Alma comenta lo que significó su vida dentro de la pandilla, desde las razones que la llevaron a formar parte de la mara hasta lo que la hizo reflexionar para retirarse.

La dura historia de esta ex pandillera que bien podría ser la historia de miles de jóvenes que se deciden por la "vida loca"que ofrece el mundo de la pandilla, pone en evidencia lo que diferentes investigaciones y estudios han venido planteando en las últimas décadas: la multicausalidad de factores que explican el fenómeno pandilleril.

A lo largo del documental, sobresale que la ausencia de factores de protección en sus familias y la falta de oportunidades de empleo y educación, conlleva a que jóvenes como Alma encuentren un refugio y sentido de pertenencia en la pandilla. Alma en su testimonio, resalta que la ausencia de sus padres, la dificultad para continuar con sus estudios y su marcada rebeldía, la llevaron a refugiarse en la pandilla. Como ella afirma: "en mi clica, encontré la familia que yo tanto buscaba".

Cabe destacar que las pandillas se asientan y reproducenparticularmente en contextos caracterizados por la marginalidad, pobreza y ausencia del Estado.En esos contextos, cobra fuerza una especie de "inclusión perversa"que ofrece la pandilla a jóvenes sin mayores perspectivas de vida.

En el testimonio de Alma, sobresale también como la violencia y el crimen son parte del ADN de estas estructuras. Alma comenta como desde un principio ella estaba consciente que las reglas en la pandilla "eran matar, 
CINE

robar y extorsionar". En esa dinámica, los jóvenes miembros de pandillas son tanto víctimas y victimarios de la violencia como consecuencia de la guerra con la pandilla rival por el control territorial o bien por el cometimiento de delitos como homicidios y extorsión.

Después de narrar algunos hechos y recuerdos de su paso por la pandilla, Alma asegura que a pesar que en un principio se sentía bien con los "hommies" (los otros miembros de la pandilla), con el paso del tiempo, su vida en la pandilla cada vez se fue haciendo más dura. Ella relata comosu participación en una serie de robos, asesinatos, hasta haber sido cómplice en muchos casos de violación, fueron situaciones que la llevaron a reflexionar y tomar la decisión de retirarse de la pandilla. Para Alma, la "vida loca" perdió sentido.

Luego de compartir una porción del mundo oscuro que vivió al ser parte de la pandilla, Alma expresa con mucho dolor y arrepentimiento y cierra su testimonio explicando que su propósito al estar frente a cámaras fue compartir lo que ella vivió y que otros jóvenes conozcan de primera mano las consecuencias del mundo pandilleril. En especial, subraya, lo difícil que es salir de ellas. Alma plantea que desde que se decide ingresar a la pandilla "tú ya no estás libre, tú ya no eres tú... eres parte del barrio, tú no te mandas, te mandan todos". Para ella, el costo de retirarse de su clica significó quedar parapléjica.

La dura historia de Alma, la cual podría ser la de miles de jóvenes miembros de pandillas en Guatemala, El Salvador y Honduras, muestra que los pandilleros no solo son hijos de la violencia, sino también se podrían considerar hijos de la exclusión social. Este tipo de documentales invitan a repensar el tratamiento del fenómeno pandilleril no sólo como un problema de seguridad. Si bien es claro que se necesita una dosis de control del delito, es importante que paralelamente y de forma más agresiva se atiendanlos factores de tipo estructural que están detrás de la reproducción social y crecimiento de las pandillas.

Sinopsis a cargo de Walter Vladimir Murcia Consultor de agenda internacional con énfasis en temas de seguridad y desarrollo 